\title{
Transcriptome sequencing and comparative transcriptome analysis of the scleroglucan producer Sclerotium rolfsii
}

Jochen Schmid*1,2, Dirk Müller-Hagen2,6, Thomas Bekel², Laura Funk2, Ulf Stahl2, Volker Sieber 1,4 and Vera Meyer2,5

\begin{abstract}
Background: The plant pathogenic basidiomycete Sclerotium rolfsii produces the industrially exploited exopolysaccharide scleroglucan, a polymer that consists of (1 T 3)- $\beta$-linked glucose with a (1 T 6)- $\beta$-glycosyl branch on every third unit. Although the physicochemical properties of scleroglucan are well understood, almost nothing is known about the genetics of scleroglucan biosynthesis. Similarly, the biosynthetic pathway of oxalate, the main byproduct during scleroglucan production, has not been elucidated yet. In order to provide a basis for genetic and metabolic engineering approaches, we studied scleroglucan and oxalate biosynthesis in S. rolfsii using different transcriptomic approaches.

Results: Two S. rolfsii transcriptomes obtained from scleroglucan-producing and scleroglucan-nonproducing conditions were pooled and sequenced using the 454 pyrosequencing technique yielding 350,000 reads. These could be assembled into 21,937 contigs and 171,833 singletons, for which 6,951 had significant matches in public protein data bases. Sequence data were used to obtain first insights into the genomics of scleroglucan and oxalate production and to predict putative proteins involved in the synthesis of both metabolites. Using comparative transcriptomics, namely Agilent microarray hybridization and suppression subtractive hybridization, we identified $\sim 800$ unigenes which are differently expressed under scleroglucan-producing and non-producing conditions. From these, candidate genes were identified which could represent potential leads for targeted modification of the S. rolfsii metabolism for increased scleroglucan yields.

Conclusions: The results presented in this paper provide for the first time genomic and transcriptomic data about $S$. rolfsii and demonstrate the power and usefulness of combined transcriptome sequencing and comparative microarray analysis. The data obtained allowed us to predict the biosynthetic pathways of scleroglucan and oxalate synthesis and to identify important genes putatively involved in determining scleroglucan yields. Moreover, our data establish the first sequence database for S. rolfsii, which allows research into other biological processes of S. rolfsii, such as hostpathogen interaction.
\end{abstract}

\section{Background}

The basidiomycete Sclerotium rolfsii is a soilborne plant pathogenic fungus causing diseases in many agricultural and horticultural plants [1-3]. However, it is also used in biotechnology as a microbial platform for the production of the exopolysaccharide (EPS) scleroglucan. This polysaccharide is a water-soluble homopolymer composed of a (1 T 3)- $\beta$-linked glucopyranose backbone with single (1

* Correspondence: j.schmid@tum.de

1 Chair of Chemistry of Biogenic Resources, Straubing Centre of Science, Technische Universität München, Schulgasse 16, 94315 Straubing, Germany Full list of author information is available at the end of the article
T 6)- $\beta$-linked glucopyranosyl branches on every third subunit [4] and traded under the commercial names Tinocare GL and Actigum. Scleroglucan shows remarkable rheological properties rendering the substance as a multipurpose compound for many industrial applications, ranging from oil recovery over food industry to cosmetics and medical applications [5-7]. Surprisingly, only very little information is available on the biosynthesis of scleroglucan formation by $S$. rolfsii $[4,7,8]$ whereas the physicochemical properties of scleroglucan are well explored [7-11]. 
According to theoretical considerations put forward by Sutherland [11,12], scleroglucan synthesis follows the general scheme for polysaccharide production in microbial systems in three major steps: substrate uptake, intracellular formation and extrusion from the cell. Uptake of glucose into the cell is mediated by glucose transporter(s), followed by phosphorylation of glucose to glucose-6-phosphate via a hexokinase reaction (EC: 2.7.1.1). After interconversion of glucose-6-phosphate to glucose1-phosphate by phospho-glucomutase (EC: 2.7.5.1), a UTP-glucose-1-phosphate uridylyltransferase (EC: 2.7.7.9) activates glucose-1-phosphate to UDP-glucose. A (1 T 3)- $\beta$-glucan synthase (EC: 2.4.1.34) polymerizes the backbone chain using UDP-glucose as monomeric precursor. The last step yielding to the (1 T 6)- $\beta$ branching at every third glucose molecule is supposed to be catalyzed by trans-D-glucosidases [12]. ${ }^{14} \mathrm{C}$ incorporation experiments evidenced that the (1 T 3)- $\beta$ chain of scleroglucan is elongated toward the non-reducing terminus and that (1 T 6)- $\beta$-linked glycosyl side residues are incorporated simultaneously as the (1 T 3)- $\beta$-glucan backbone is elongated $[13,14]$.

Several empirical studies have been performed to identify optimum medium composition for EPS production by $S$. rolfsii [15-21]. Interestingly, medium conditions favoring scleroglucan production have been reported to increase the amount of secreted oxalate as well $[22,23]$. The biosynthesis of scleroglucan has thus been proposed to be closely linked to the synthesis of oxalate; a reducing agent and strong acid involved in the infection process of S. rolfsii $[24,25]$. During industrial scleroglucan production, however, the formation of the by-product oxalate is undesirable as it lowers the productivity of the process and negatively interferes with downstream processing of scleroglucan $[7,18]$. For some of its applications, e.g. in cosmetics and food industry, a cost intensive removal of oxalate is necessary.

Microbial oxalate is assumed to be synthesized in the glyoxylate cycle (GLOX), which is the anaplerotic pathway during growth on $\mathrm{C} 2$-carbon sources. Glyoxylate and succinate are the products of the isocitrate lyase reaction, and glyoxylate is either further oxidized to oxalate via the glyoxylate oxidase or used as precursor for malate synthesis. Although for basidiomycetes the cellular role of oxalate is still not clarified, it has been reported to be important for free radical formation, iron and calcium chelation as well as pectin and cellulose hydrolysis [2629]. In phytopathogenic fungi, oxalate has been described as a very important factor contributing to fungal virulence. One role of oxalate is to lower the $\mathrm{pH}$ of the ambient environment, resulting in increased fungal polygalacturonase activity necessary for plant cell wall degradation $[23,27,28]$. Other roles include sequestration of calcium from cell walls, hydrolysis of plant pectin, suppression of plant defense responses and induction of the programmed cell death in plants [30-32].

Understanding the genetic basis for scleroglucan and oxalate biosynthesis is a prerequisite for the design of genetically engineered strains with improved scleroglucan yields. However, the genome of S. rolfsii has not been sequenced yet and DNA sequences have been published for only a few $S$. rolfsii genes. To overcome this obstacle, we applied the massively parallel short-read 454 pyrosequencing technology to sequence the transcriptome of $S$. rolfsii. From the assembled and annotated unigene sequences, we predicted genes particularly involved in EPS and oxalate metabolism. Additionally, we performed a global suppression subtractive hybridization (SSH) approach to isolate and identify genes up-regulated under scleroglucan-producing conditions. We used the sequence data obtained from the 454 sequencing and from the SSH approaches to finally develop Agilent microarray chips to perform comparative gene expression profiling for $S$. rolfsii grown in scleroglucan-producing and scleroglucan-nonproducing conditions and to identify genes differentially expressed under both conditions.

\section{Results and Discussion \\ Designing scleroglucan-producing and scleroglucan- nonproducing media}

A basic requirement for this work was the development of two cultivation media for S. rolfsii, which should provide sufficient growth and a comparable biomass production, however with significant differences in EPS production. In order to identify such media compositions, we used the synthetic EPS medium proposed by Farina et al [15], and altered both the nature and concentration of the carbon (glucose, fructose, sucrose; 25-220 $\mathrm{mM})$ and nitrogen $\left(\mathrm{NH}_{4} \mathrm{Cl}, \mathrm{NaNO}_{3},\left(\mathrm{NH}_{4}\right)_{2} \mathrm{SO}_{4} ; 17-280\right.$ $\mathrm{mM}$ ) sources. S. rolfsii was cultivated in these media and the formation of scleroglucan and oxalate was monitored over time (data not shown). As shown in Figure 1A, scleroglucan production was high in medium containing 220 $\mathrm{mM}$ Glc and $35 \mathrm{mM} \mathrm{NaNO}_{3}$ (designated EPSmax13) and lower in medium containing $220 \mathrm{mM}$ Fru and $35 \mathrm{mM}$ $\mathrm{NH}_{4} \mathrm{Cl}$ (designated EPSmin17). At $30 \mathrm{~h}$ of cultivation, $S$. rolfsii produced scleroglucan in EPSmax13 medium but to a slightly lesser extent in EPSmin 17 medium. Sufficient amounts and significant differences in scleroglucan production are detectable after $37 \mathrm{~h}$ of cultivation, whereas biomass accumulation was comparable. We thus decided to choose the $37 \mathrm{~h}$ time point for the comparative analysis. Interestingly, cultures of $S$. rolfsii grown in EPSmax13 and EPSmin 17 media displayed similar $\mathrm{pH}$ and oxalate profiles, suggesting that oxalate production is rather cou- 
A

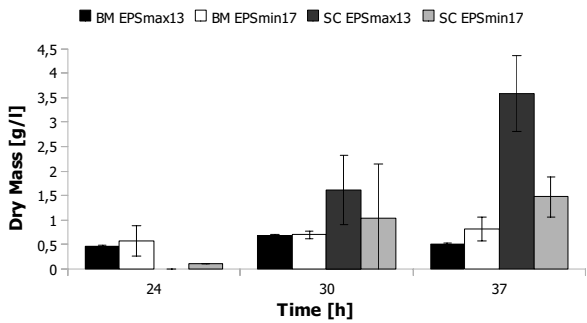

B

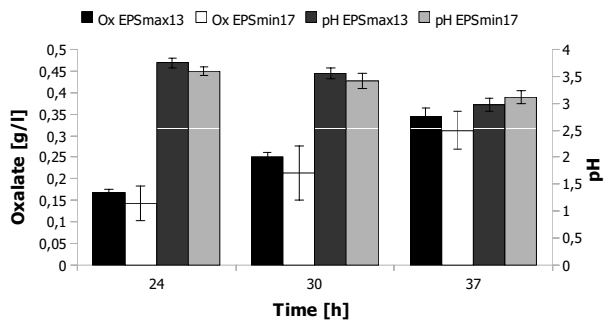

Figure 1 Growth of S. rolfsii and metabolite production in EPSmax13 and EPSmin 17 medium. S. rolfsii was cultivated in $50 \mathrm{ml}$ medium at $28^{\circ} \mathrm{C}$ up to $37 \mathrm{~h}$. Cultures were harvested at the time points indicated, and the dry weight biomass (BM), scleroglucan (SC), oxalate and the medium $\mathrm{pH}$ determined. Mean values of a biological duplicate experiment are shown.

pled to growth and biomass formation than to scleroglucan synthesis (Figure 1B).

\section{4 pyrosequencing and data analysis}

Total RNA extracted from $37 \mathrm{~h}$ old cultures of $S$. rolfsii grown in EPSmin 17 and EPSmax13 medium were pooled in a 1:1 ratio to guarantee equal predominance of both RNA populations and subsequently reversed transcribed into cDNA. The mixed cDNA sample was sequenced by 454 Life Sciences ${ }^{\mathrm{Tt}}$. The rationale behind combining both mRNA populations was to increase transcriptome coverage. Triplicate sequencing runs resulted in 356,098 single reads composed of 3.68 million bases (Table 1). Using the 454 Life Sciences $^{\mathrm{Tm}}$ Newbler software, these reads were trimmed and assembled into 21,937 contiguous sequences and 171,833 singletons (Table 1, Additional file 1) and are later on referred to as unigenes. A complete list of all unigenes has been deposited at the NCBI Sequence Read archive (SRA, http://www.ncbi.nlm.nih.gov/sra) under accession number SRA012273.1.

All unigenes obtained were functionally analyzed via the Sequence Analysis and Management System (SAMS). This software platform was originally developed to support the computational analysis of shotgun genome sequencing projects [33]. However, in addition to quality assessments, SAMS is well suited for the annotation of short sequence fragments and as an annotation pipeline also includes standard bioinformatics tools such as BLAST [34]. We thus used SAMS to analyze and func-
Table 1: Sequencing, assembly and data analysis.

\begin{tabular}{ll}
\hline Sequencing reads & 356,098 \\
Trimmed reads & 343,410 \\
$\begin{array}{l}\text { Singletons } \\
\text { Average length singletons } \\
\text { (bases) }\end{array}$ & 171,833 \\
Contigs & 21,937 \\
Largest contig size (bases) & 1,256 \\
$\begin{array}{l}\text { Average large contig size } \\
\text { (bases) }\end{array}$ & 654 \\
No. of bases in large contigs & 286,124 \\
No. of large contigs & 437 \\
No. of bases & $3,681,160$ bases \\
\hline
\end{tabular}

tionally annotate the S. rolfsii unigenes. The analysis pipeline was set up with different BLAST tools and databases: BLAST2 $\times$ versus the NCBI NR protein database (E-value cut-off of 10-5), BLAST2 $\times$ versus the KOG protein database (E-value cut-off of 10-5), BLAST2n versus the NCBI NT nucleotide database (E-value cut-off of 105) and TBLASTx 2 versus the NCBI NR/NT database, Evalue cut-off of 10-5). The EuKaryotic Orthologous Groups database (KOG) is essentially the eukaryotic version of the Clusters of Orthologous Groups database (COG; http://www.ncbi.nlm.nih.gov/COG/).

A total of 6,951 sequences were assigned to one or more KOG functional categories. The remaining sequences were excluded by the chosen cut-off $E$ value of $10^{-5}$. To evaluate the completeness of the transcriptomic data collection, we searched the unigenes for the presence of genes predicted to function in four primary carbon metabolic pathways - glycolysis, pentose phosphate pathway, TCA and glyconeogenesis. Annotated sequences were found for every step of the four pathways (data not shown), suggesting that the transcriptomic library could represent a nearly complete sequence database for the $S$. rolfsii transcriptome. The annotated unigene functions cover a broad range of KOG categories (Figure 2, Additional file 2), with the majority of genes grouping into the metabolism category. Among the functional KOG categories, we were particularly interested in the categories 'Carbohydrate transport and metabolism $(\mathrm{G})$ ' and 'Energy production and conversion $(\mathrm{C})$ ' as they were supposed to contain unigenes which participate in scleroglucan and oxalate metabolism. An overview of all unigenes allocated into both categories is given in Additional file 3. From this list, unigenes were selected which could potentially be involved in each of the five steps of scleroglucan biosynthesis (Figure 3). Surprisingly, only one potential candidate glycosyltransferase, presumed to catalyze the last step in scleroglucan synthesis, was iden- 


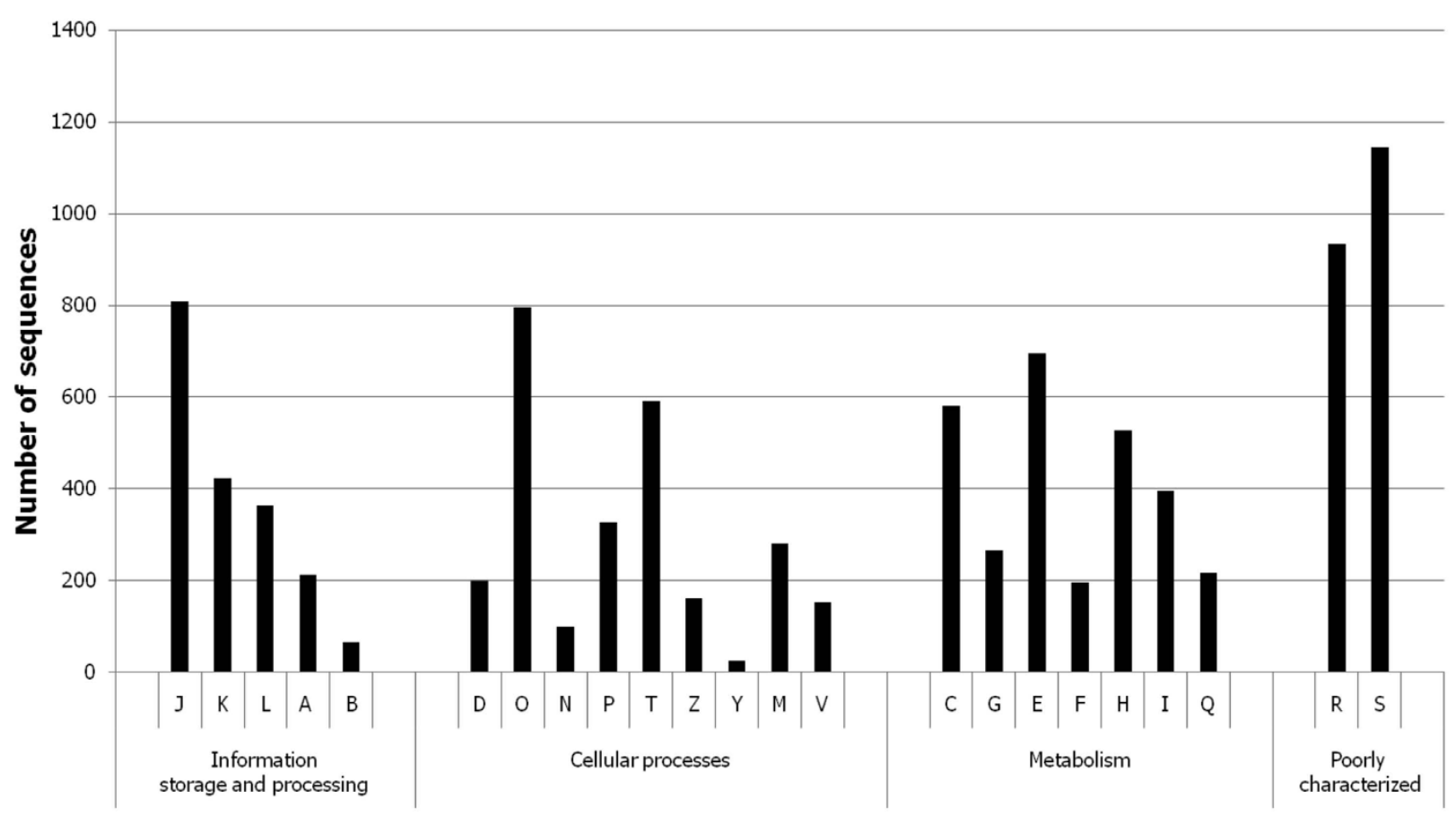

Figure 2 KOG categorization of S. rolfsii unigenes. Categories are abbreviated as follows: J, translation, ribosomal structure and biogenesis; $K$, transcription; L, replication, recombination and repair; A, RNA processing and modification; B, chromatin structure and dynamics; D, cell cycle control, cell division, chromosome partitioning; $\mathrm{O}$, posttranslational modification, protein turnover, chaperones; $\mathrm{N}$, cell motility; $\mathrm{P}$, inorganic ion transport and metabolism; T, signal transduction mechanisms; $Z$, Cytoskeleton; $Y$, Nuclear structure, $M$, cell wall/membrane/envelope biogenesis; $V$, defense mechanisms; $C$, energy production and conversion; $\mathrm{G}$, carbohydrate transport and metabolism; E, amino acid transport and metabolism; F, nucleotide transport and metabolism; $\mathrm{H}$, coenzyme transport and metabolism; I, lipid transport and metabolism; Q, secondary metabolites biosynthesis, transport and catabolism; R, general function prediction only; S, function unknown.

tified. Lacking more direct hits, we screened the complete 171,833 singletons for the presence of a predicted glycosyltransferase unigene and retrieved one additional positive hit (D6LAZMP02HU01 M, 109 bases).

With respect to oxalate metabolism, we could retrieve matching unigenes for 9 out of 12 possible enzymatic reactions (Figure 4 and Table 2). As three hits potentially encode an oxaloacetate hydrolase (reaction 1 in Figure 4) but none a glyoxylate oxidase (reaction 2 in Figure 4), it can be suggested that the main route for oxalate synthesis in S. rolfsii is via oxaloacetate. This would be in good agreement with previous findings which demonstrated that the most important pathway leading to oxalate formation in asco- and basidiomycetes is catalyzed via an oxaloacetate hydrolase and thus solely depends on oxaloacetate as precursor and not on glyoxylate [35-37]. On the other hand, it has been reported for S. rolfsii that the enzyme glycolate oxidase (reaction 12 in Figure 4) also accepts glyoxylate as substrate and oxidizes it to oxalate $[20,38]$. Four contigs show considerable homology to glycolate oxidases (Table 2), which thus could be candidate genes for such an enzyme.
In terms of oxalate degradation, no hits were identified for an oxalate oxidase (reaction 11 in Figure 4) and an oxalate decarboxylase (reaction 7 in Figure 4), but several unigenes matched a formate dehydrogenase (reaction 8 in Figure 4). We propose two possible explanations for this finding. Either the main pathway for oxalate degradation is still the oxalate decarboxylase -- formate dehydrogenase route but the oxalate decarboxylase gene was expressed on a very low level and therefore not found among the mRNA population(s) used for sequencing. Or S. rolfsii does not use the oxalate decarboxylase -- formate dehydrogenase pathway for oxalate degradation and the formate dehydrogenase enzyme rather has a function in anaerobic respiration as shown for Fusarium oxysporum $[39,40]$.

As the lack of detection for unigenes encoding for an oxalate oxidase and oxalate decarboxylase could be due to their low expression levels, we screened the genomic DNA of $S$. rolfsii via PCR using primers designed from respective fungal and plant gene sequences (see Methods). Basically, either one of both enzymes have been reported to be present in basidiomycetes, e.g. an oxalate oxidase is crucial for lignin degradation by the white rot 


\section{Glucose}<smiles>CCCC</smiles>

Glucose<smiles>CC(C)I</smiles>

Glucose-6-phosphate<smiles>CCCC</smiles>

Glucose-1-phosphate<smiles>CC(C)(C)C</smiles>

UDP-glucose<smiles>CCCC</smiles>

$(1 \rightarrow 3)-\beta$-glucan

$\downarrow 5$

$(1 \rightarrow 3) ;(1 \rightarrow 6)-\beta-$ glucan

\section{Sugar transporter}

contig05623, contig05747, contig09346, contig13275

\section{Hexokinase}

contig21210, contig16348, contig16349, contig09822 contig20335

\section{Phosphoglucomutase}

contig 12803, contig 14140, contig20960, contig16995

\section{UTP-glucose-1-phosphate- uridilyltransferase contig00105, contig10184, contig14249}

4 ( $1 \rightarrow 3)$ - $\beta$-glucan synthase contig12682, contig07131, contig05470

\section{Glycosyltransferase/Glucosidase} contig05325

Figure 3 Candidate unigenes potentially involved in scleroglucan biosynthesis. Unigenes with predicted functions in one of these steps are indicated with their contig code.

fungus Ceriopsis subvermispora [41] and a oxalate decarboxylase is important for the brown rot fungus Flammulina velutipes for the survival under low external $\mathrm{pH}$ conditions [42]. All our PCR attempts to isolate a DNA sequence encoding an oxalate degrading enzyme were only successful for an oxalate oxidase but not for an oxalate decarboxylase (data not shown). We were able to isolate one DNA fragment (designated oxox), which showed $32 \%$ similarity to the barley oxo $X$ gene, suggesting that the oxalate oxidase reaction is the likely oxalate degradation route in S. rolfsii.

\section{Comparative transcriptomics using suppression subtractive hybridization}

We used a suppression subtractive hybridization (SSH) approach to isolate cDNA species which are only present or enriched in $S$. rolfsii when grown in EPSmax13 medium compared to EPSmin 17 medium. The advantage of the SSH approach is that also low abundant mRNA species can be isolated. The mRNA isolated from $S$. rolfsii cultivated for $37 \mathrm{~h}$ in EPSmax13 medium was used as 'tester' and mRNA isolated from 37 h old S. rolfsii cultures cultivated in EPSmin 17 medium served as 'driver'. A total of 400 transformants representing cDNAs induced under scleroglucan-producing conditions were isolated. 180 of these clones were randomly selected and screened by reverse Northern hybridization for differential expression (Figure 5 and data not shown). 49 of the 180 screened cDNA clones showed considerable differences when hybridized with total cDNAs from scleroglucan-producing and scleroglucan-nonproducing conditions, respectively, confirming that these genes are up-regulated during scleroglucan biosynthesis. The 49 differentially expressed cDNAs were sequenced (Additional file 4), analyzed via TBLASTx and assigned to their predicted functional activity within different biochemical pathways (Table 3). In addition, the BioEdit tool http:// www.mbio.ncsu.edu/BioEdit/bioedit.html was applied to blast and align the SSH unigenes against the 21,937 contigs identified via 454 sequencing (E-value cut-off of $10^{-5}$ ). 


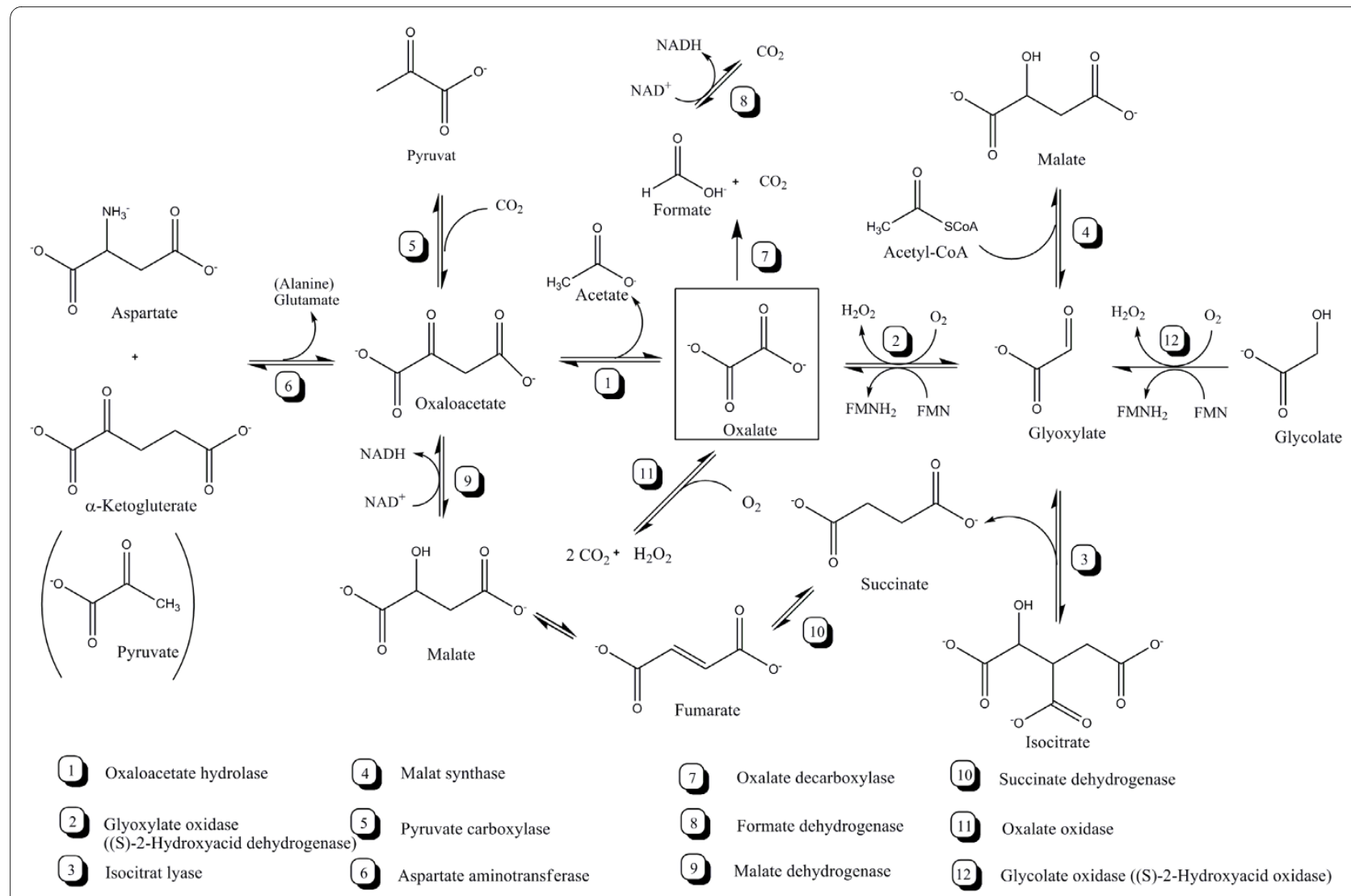

Figure 4 Biochemical pathways involved in microbial oxalate metabolism. A literature survey of microbial and especially fungal oxalate metabolism was conducted to obtain an inventory of all possible metabolic routes for oxalate synthesis and degradation. Unigenes with predicted functions in one of these steps are indicated with their contig code in Table 2.

For the majority of the SSH unigenes, we could identify homologous 454 unigenes (Table 3).

Interestingly, we isolated not only genes predicted to function in scleroglucan and oxalate metabolism (e.g. UTP-glucose-1-phosphate uridylyltransferase, two aspartate aminotransferases, and two formate dehydrogenases) but also genes known to play fundamental roles in primary metabolism. For example, pyruvate decarboxylase (marker enzyme for oxygen limitation), isocitrate dehydrogenase (key enzyme of TCA), oxoglutarate dehydrogenase (enzyme of TCA and key enzyme for ammonia assimilation), acyl-CoA-dehydrogenase (first and ratelimiting step of fatty acid oxidation) and glycogen phosphorylase (crucial for survival under low energy supply) were among the predicted proteins.

\section{Comparative transcriptomics using Agilent microarray hybridization}

Complementary to the SSH approach; we performed gene expression profiling to identify genes up- and downregulated during scleroglucan-producing conditions. In order to manufacture respective Agilent microarrays, ten different $60 \mathrm{bp}$ long probes were designed (Additional file
5) and in situ synthesized for all of the 454 and SSH unigenes $(\sim 22,000)$. The specificity of the probes was analyzed in a test hybridization run using pooled cDNA populations from $S$. rolfsii cultivated for $37 \mathrm{~h}$ in EPSmax13 and EPSmin17 medium (data not shown). Based on the results, two probes per unigene were selected for the design of Agilent Multiplex 44K Arrays (Additional file 6). The arrays were hybridized with $S$. rolfsii cDNA, obtained from $37 \mathrm{~h}$ cultivations in EPSmax13 and EPSmin17 medium, respectively. Hybridizations were performed in triplicate using mRNA isolated from three independent cultures (biological triplicate, Additional files 7, 8, 9, 10, 11, 12 and 13). After normalization based on quantiles, hybridization clustering experiments were performed to control both experimental conditions. Based on this quality check, we had to exclude one of the triplicate samples from further analysis (EPSmin17 experiment, Sample B) as it did not cluster with the other two EPSmin17 samples (Additional file 14).

For the comparison of the EPSmax13 triplicate versus the EPSmin17 duplicate arrays, we used an arbitrary chosen fold change of 2 to define unigenes as differently 
Table 2: Unigenes with predicted enzyme function related to oxalate metabolism.

\begin{tabular}{|c|c|c|}
\hline No. & Enzyme & Contig \\
\hline 1 & $\begin{array}{l}\text { Oxaloacetate } \\
\text { hydrolase }\end{array}$ & contig05630 contig03818 contig 14763 \\
\hline 2 & Glyoxylate oxidase & No hit \\
\hline 3 & Isocitrate lyase & contig 14763 contig 15770 contig 18874 contig 18218 contig 00175 contig 08937 \\
\hline 4 & Malate synthase & contig00888 contig05791 \\
\hline 5 & Pyruvate carboxylase & contig00420 contig 21272 \\
\hline 6 & $\begin{array}{l}\text { Aspartate } \\
\text { aminotransferase }\end{array}$ & contig 02946 contig 08150 contig 16197 contig 17262 contig 19058 contig19059 contig20005 \\
\hline 7 & $\begin{array}{l}\text { Oxalate } \\
\text { decarboxylase }\end{array}$ & No hit \\
\hline 8 & $\begin{array}{l}\text { Formate } \\
\text { dehydrogenase }\end{array}$ & $\begin{array}{l}\text { contig } 00580 \text { contig } 04723 \text { contig } 04947 \text { contig } 07858 \text { contig } 11312 \text { contig13166 contig15432 } \\
\text { contig15438 contig } 16572 \text { contig } 16914 \text { contig } 17132 \text { contig } 17885 \text { contig18254 contig21037 }\end{array}$ \\
\hline 9 & $\begin{array}{l}\text { Malate } \\
\text { dehydrogenase }\end{array}$ & contig 02004 contig 07487 e contig 12545 contig 16174 contig 18066 contig 19518 contig21582 \\
\hline 10 & $\begin{array}{l}\text { Succinate } \\
\text { dehydrogenase }\end{array}$ & $\begin{array}{l}\text { contig11748 contig12058 contig } 05741 \text { contig } 07994 \text { contig14088 contig04161 contig15005 } \\
\text { contig20092 contig17475 contig19516 contig18382 contig20164 contig20896 contig19935 } \\
\text { contig2 } 1237 \text { contig16039 contig19560 }\end{array}$ \\
\hline 11 & Oxalate oxidase & No hit \\
\hline 12 & Glycolate oxidase & contig 15511 contig 21032 contig 08342 contig 17818 \\
\hline
\end{tabular}

T Summary of the S. rolfsii contigs giving at least one hit when analyzed with one of the four BLAST tools (E-value cut-off of $10^{-5}$ ) to the enzymes catalyzing reactions 1-12 according to Figure 4.

expressed (Students t-test; $\mathrm{p}<0.05$ ). Applying this filter, expression of a total of 723 unigenes did significantly vary between both conditions, whereby 356 unigenes were upand 367 down-regulated under EPSmax13 condition when compared to the EPSmin17 condition. A comprehensive list of all differentially expressed unigenes is depicted in the Additional file 15. As not all of the 723 unigenes displayed a KOG annotation, we manually reannotated this gene list using TBLASTx or BLASTN (Evalue cut-off of $10^{-5}$ ) and classified the predicted protein functions according to the Functional Catalogue (FunCat) [43]. We could thereby assign putative FunCats to 267 unigenes, out of which 138 were up-regulated and 129 down-regulated in $S$. rolfsii when cultivated in EPSmax13 medium (Additional file 15, Figure 6).
The functional categories with the largest number of differently expressed unigenes are the categories 'Metabolism' and 'Transport' (Figure 6). Among these are four unigenes which we had isolated via the SSH approach (e.g. glycogen phosphorylase, UDP-glucose-4-epimerase, formate dehydrogenase; Table 4). The high fold change cut-off used for microarray analysis as well as the lower sensitivity of microarrays compared to SSH probably limited the amount of overlapping hits. Nine unigenes predicted to encode polysaccharide-acting enzymes were upregulated when $S$. rolfsii was cultivated in EPSmax13 medium (Table 4), thus representing potential candidate genes involved in scleroglucan elongation and branching. Moreover, many up-regulated unigenes fall into the group of ergosterol and sphingolipid metabolic proteins (Table 4). Finally, various unigenes assigned to transporters 


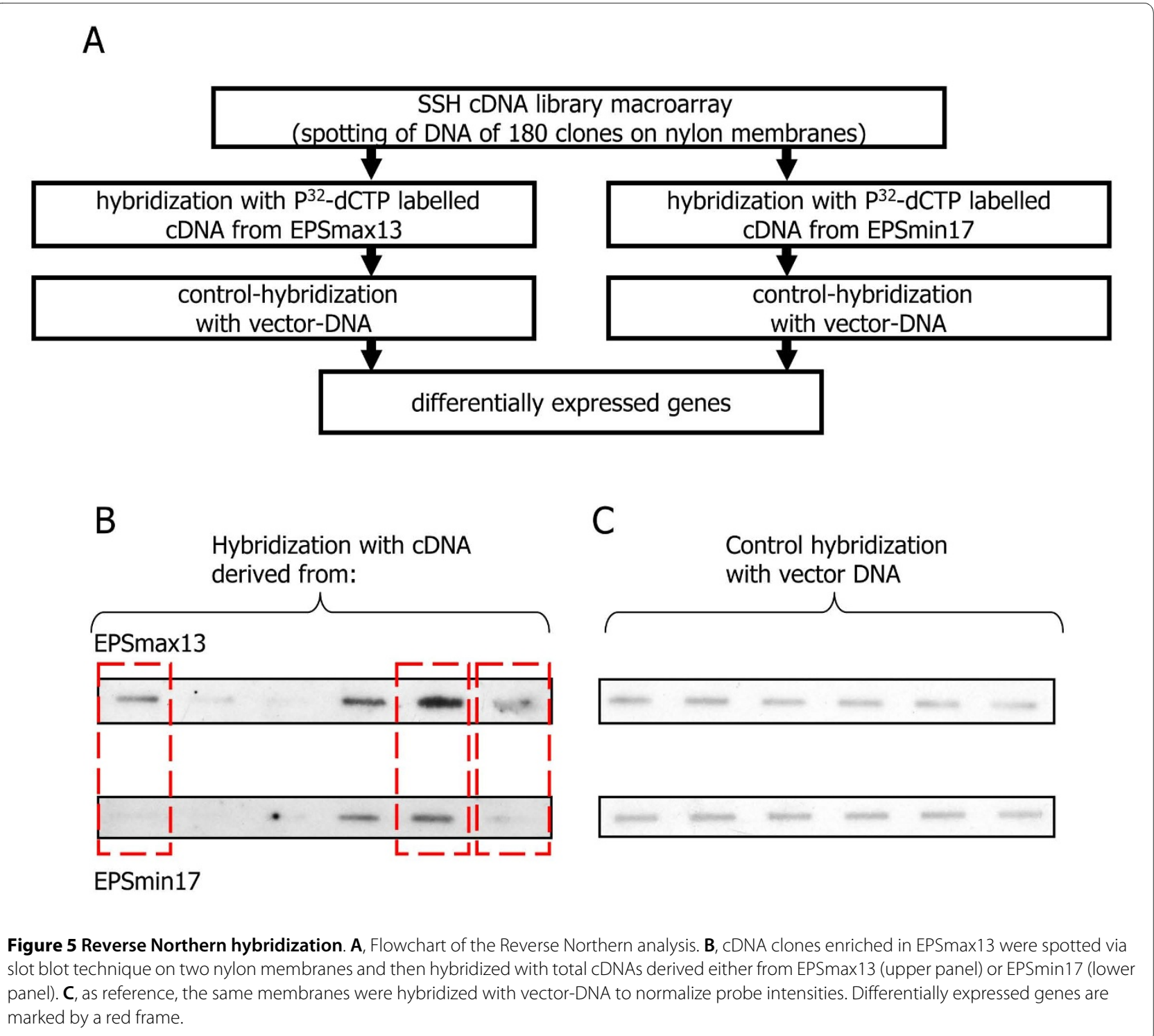

(ions, amino acids, peptides, lipids) and oxidoreductases (e.g. aryl-alcohol dehydrogenases) displayed altered expression under EPSmax13 conditions (Additional file 15). These transcriptional changes could imply that scleroglucan synthesis might be coupled to the cellular ion homeostasis machinery. Such a scenario would be in agreement with the overall concept that microbial EPS production is also an adaptive response towards environmental salt and osmotic stress [44-47].

\section{Conclusions}

In this study, we used different strategies to reveal genes involved in scleroglucan synthesis and oxalate metabolism of Sclerotium rolfsii, a fungus that lacks a sequenced genome. In sum, three independent transcriptomic approaches were applied, which together uncovered candidate genes for each predicted step of scleroglucan syn- thesis, oxalate synthesis and oxalate degradation. Many of these genes were unraveled in both global comparative transcriptomic analyses, making them as prime candidates for further analyses.

The insights into the genetics and transcriptome of scleroglucan synthesis obtained in this work are to our knowledge the first gained for any EPS produced by a basidiomycete. The sequence data covers a nearly complete set of genes transcribed in $S$. rolfsii and provides an important resource for studying the biology and pathogenesis of $S$. rolfsii.

\section{Methods}

\section{Cultivation conditions}

$S$. rolfsii strain ATCC15205 was cultivated at $28^{\circ} \mathrm{C}$ in shake flasks containing $50 \mathrm{ml}$ EPS medium (C-source, $\mathrm{N}$ source, $2 \mathrm{~g} / \mathrm{l} \mathrm{K}_{2} \mathrm{HPO}_{4}, 0.5 \mathrm{~g} / \mathrm{l} \mathrm{KCl}, 0.5 \mathrm{~g} / \mathrm{l} \mathrm{MgSO}{ }_{4}^{*} 7 \mathrm{H}_{2} \mathrm{O}$, 
Table 3: Unigenes identified via SSH and Reverse Northern hybridization that display increased expression in EPSmax13 medium.

\begin{tabular}{|c|c|c|c|}
\hline Target ID & Predicted function (TBLASTx) & Length $(\mathbf{b p})^{*}$ & Homologous 454 unigene \\
\hline \multicolumn{4}{|c|}{ Carbohydrate metabolism } \\
\hline \multirow[t]{2}{*}{$12 \mathrm{VII}-3$} & Glucan phosphorylase & 421 & contig00741 \\
\hline & & & contig15192 \\
\hline B5 & $\begin{array}{l}\text { UTP-glucose-1-phosphate } \\
\text { uridylyltransferase }\end{array}$ & 429 & contig14249 \\
\hline \multirow[t]{4}{*}{ F4 } & UDP-glucose-4-epimerase & 531 & contig14591 \\
\hline & & & contig16714 \\
\hline & & & contig05705 \\
\hline & & & contig19066 \\
\hline \multirow[t]{2}{*}{ D1 } & Glucosamine-6-phosphate isomerase & 441 & contig18828 \\
\hline & & & contig19082 \\
\hline \multirow[t]{2}{*}{ E3 } & Beta-fructofuranosidase & 419 & contig14026 \\
\hline & & & contig07977 \\
\hline C2 & Glycogen phosphorylase & 470 & contig13256 \\
\hline \multirow[t]{2}{*}{$7 \mathrm{VI}-14$} & Glycogen phosphorylase & 421 & contig00741 \\
\hline & & & contig15192 \\
\hline \multirow[t]{2}{*}{$3 \mathrm{VI}-7$} & Isocitrate dehydrogenase & 546 & contig15308 \\
\hline & & & contig19633 \\
\hline $9 \mathrm{VI}-19$ & Oxoglutarate dehydrogenase & 325 & No hit \\
\hline \multirow[t]{2}{*}{$33 \mathrm{XI}-28$} & Pyruvate decarboxylase & 318 & contig19196 \\
\hline & & & contig19387 \\
\hline E4 & Pyruvate decarboxylase & 242 & No hit \\
\hline \multirow[t]{2}{*}{ G2 } & Pyruvate decarboxylase & 236 & contig19196 \\
\hline & & & contig19387 \\
\hline \multirow[t]{2}{*}{ G8 } & Pyruvate decarboxylase & 242 & contig03793 \\
\hline & & & contig15593 \\
\hline D2 & Phosphopyruvate hydratase & 183 & No hit \\
\hline \multirow[t]{2}{*}{ B8 } & Trehalose phosphorylase & 178 & contig17258 \\
\hline & & & contig19103 \\
\hline \multirow[t]{3}{*}{ F3 } & Mannitol-1-phosphate dehydrogenase & 357 & contig21872 \\
\hline & & & contig13513 \\
\hline & & & contig19371 \\
\hline $4 \mathrm{VI}-8$ & Formate dehydrogenase & 186 & contig08513 \\
\hline \multirow[t]{5}{*}{$27 \mathrm{~V}-36$} & Formate dehydrogenase & 486 & contig04947 \\
\hline & & & contig11312 \\
\hline & & & contig16572 \\
\hline & & & contig17132 \\
\hline & & & contig13166 \\
\hline
\end{tabular}

Lipid metabolism

$29 \mathrm{X}-12$ 
Table 3: Unigenes identified via SSH and Reverse Northern hybridization that display increased expression in EPSmax13 medium. (Continued)

\begin{tabular}{|c|c|c|c|}
\hline \multirow[t]{2}{*}{$34 \mathrm{XI}-34$} & Oleate 12-hydroxylase gene & 337 & contig00730 \\
\hline & & & contig19568 \\
\hline \multirow[t]{3}{*}{21 VIII-38 } & Multifunctional beta-oxidation protein & 589 & contig15214 \\
\hline & & & contig15066 \\
\hline & & & contig12394 \\
\hline \multirow[t]{3}{*}{$8 \mathrm{VI}-18$} & Acyl-CoA-Dehydrogenase & 877 & contig11819 \\
\hline & & & contig00728 \\
\hline & & & contig07196 \\
\hline \multicolumn{4}{|c|}{ Transport } \\
\hline \multirow[t]{2}{*}{$13 \mathrm{VII}-5$} & Endoplasmic reticulum-derived transport & 451 & contig14573 \\
\hline & & & contig13652 \\
\hline \multirow[t]{4}{*}{ A3 } & Copper transporter & 481 & contig15666 \\
\hline & & & contig 14830 \\
\hline & & & contig02543 \\
\hline & & & contig18312 \\
\hline \multicolumn{4}{|c|}{ Amino acid metabolism } \\
\hline 22 VIII-45 & Acetylornithine aminotransferase & 146 & No hit \\
\hline $6 \mathrm{VI}-12$ & Acetylornithine aminotransferase & 140 & No hit \\
\hline \multirow[t]{3}{*}{21 VIII-38 } & Aminotransferase & 589 & contig15214 \\
\hline & & & contig15066 \\
\hline & & & contig12394 \\
\hline A2 & Aspartate aminotransferase & 476 & No hit \\
\hline \multirow[t]{3}{*}{ B7 } & Aspartate aminotransferase & 538 & contig16197 \\
\hline & & & contig17262 \\
\hline & & & contig08150 \\
\hline \multicolumn{4}{|c|}{ Oxidative stress } \\
\hline D4 & Manganese superoxide dismutase & 229 & contig14464 \\
\hline \multicolumn{4}{|l|}{ Others } \\
\hline \multirow[t]{4}{*}{ D3 } & $\begin{array}{l}\text { Superfamily of calcium sensors and } \\
\text { calcium signal modulators }\end{array}$ & 351 & contig18978 \\
\hline & & & contig15800 \\
\hline & & & contig15801 \\
\hline & & & contig16990 \\
\hline \multirow[t]{2}{*}{$18 \mathrm{VII}-50$} & ATP synthase vacuolar proton pump & 358 & contig05644 \\
\hline & & & contig 12704 \\
\hline 20 VIII-21 & GAL4-like DNA-binding domain & 340 & contig04517 \\
\hline $31 x-30$ & $\begin{array}{l}\text { Plasma membrane } \mathrm{H}+\text { transporting } \\
\text { ATPase }\end{array}$ & 348 & contig14871 \\
\hline B4 & Intradiol dioxygenase & 570 & No hit \\
\hline
\end{tabular}


Table 3: Unigenes identified via SSH and Reverse Northern hybridization that display increased expression in EPSmax13 medium. (Continued)

\begin{tabular}{|c|c|c|c|}
\hline \multicolumn{4}{|c|}{ Hypothetical } \\
\hline A4 & hypothetical protein UM02463.1 & 352 & contig 16014 \\
\hline $14 \mathrm{VII}-6$ & XP_001828655.1 CC1G_10527 & 345 & No hit \\
\hline $24 \mathrm{IV}-17$ & XP_001873967.1 & 470 & No hit \\
\hline \multirow[t]{2}{*}{$28 X-11$} & XP_001875220.1 & 624 & contig16711 \\
\hline & & & contig08447 \\
\hline \multirow[t]{4}{*}{$5 \mathrm{VI}-11$} & XP_001873416.1 & 392 & contig01594 \\
\hline & & & contig20088 \\
\hline & & & contig21715 \\
\hline & & & contig 15050 \\
\hline \multirow[t]{4}{*}{ B2 } & XP_001830146.1 CC1G_09306 & 540 & contig20176 \\
\hline & & & contig17567 \\
\hline & & & contig17591 \\
\hline & & & contig21673 \\
\hline $15 \mathrm{VII}-9$ & Transcription factor & 352 & No hit \\
\hline \multirow[t]{3}{*}{ B6 } & No hit & 590 & contig02865 \\
\hline & & & contig11989 \\
\hline & & & contig00561 \\
\hline A8 & No hit & 193 & No hit \\
\hline A7 & No hit & 193 & No hit \\
\hline \multirow[t]{3}{*}{$1 \mathrm{VI}-4$} & No hit & 207 & contig14768 \\
\hline & & & contig20467 \\
\hline & & & contig09075 \\
\hline \multirow[t]{2}{*}{$11 \mathrm{VII}-2$} & No hit & 241 & contig 15360 \\
\hline & & & contig15302 \\
\hline \multirow[t]{3}{*}{ G7 } & No hit & 537 & contig21711 \\
\hline & & & contig12931 \\
\hline & & & contig16495 \\
\hline \multirow[t]{3}{*}{ C6 } & No hit & 602 & contig02865 \\
\hline & & & contig11989 \\
\hline & & & contig00561 \\
\hline \multirow[t]{3}{*}{ F8 } & No hit & 367 & contig16532 \\
\hline & & & contig19793 \\
\hline & & & contig01157 \\
\hline
\end{tabular}

* The DNA sequences of all SSH unigenes are given in Additional file 4.

$0.05 \mathrm{~g} / 1 \mathrm{FeSO}_{4} * 7 \mathrm{H}_{2} \mathrm{O}, 1 \mathrm{~g} / \mathrm{l}$ yeast extract, $0.7 \mathrm{~g} / \mathrm{l}$ citric acid $7^{*} \mathrm{H}_{2} \mathrm{O} . \mathrm{pH} 4.5$ ) [15]. EPSmax13 contained 40 g/l glucose and $3.0 \mathrm{~g} / \mathrm{l} \mathrm{NaNO}_{3}$ as $\mathrm{C}$ - and $\mathrm{N}$-sources, whereas EPSmin 17 used $40 \mathrm{~g} / \mathrm{l}$ fructose and $1.9 \mathrm{~g} / \mathrm{l} \mathrm{NH}_{4} \mathrm{Cl}$, respectively.

\section{Analytical measurements}

In order to determine $S$. rolfsii biomass from liquid cultures, $40 \mathrm{~g}$ of each culture broth were sampled, preheated to $56^{\circ} \mathrm{C}$ and subjected to enzymatic cell wall degradation (1 mg Glucanex/g broth). After incubation for $30 \mathrm{~min}$ at $56^{\circ} \mathrm{C}$, Glucanex was heat-inactivated $\left(90^{\circ} \mathrm{C}, 20 \mathrm{~min}\right)$ and the sample cooled down to room temperature. The initial weight ( $40 \mathrm{~g}$ ) was re-adjusted by adding water and $30 \mathrm{~g}$ of this solution were centrifuged to harvest the biomass. The dry weight was determined after the wet biomass pellet was vacuum-dried over night $\left(12 \mathrm{~h}, 60^{\circ} \mathrm{C}\right)$. 


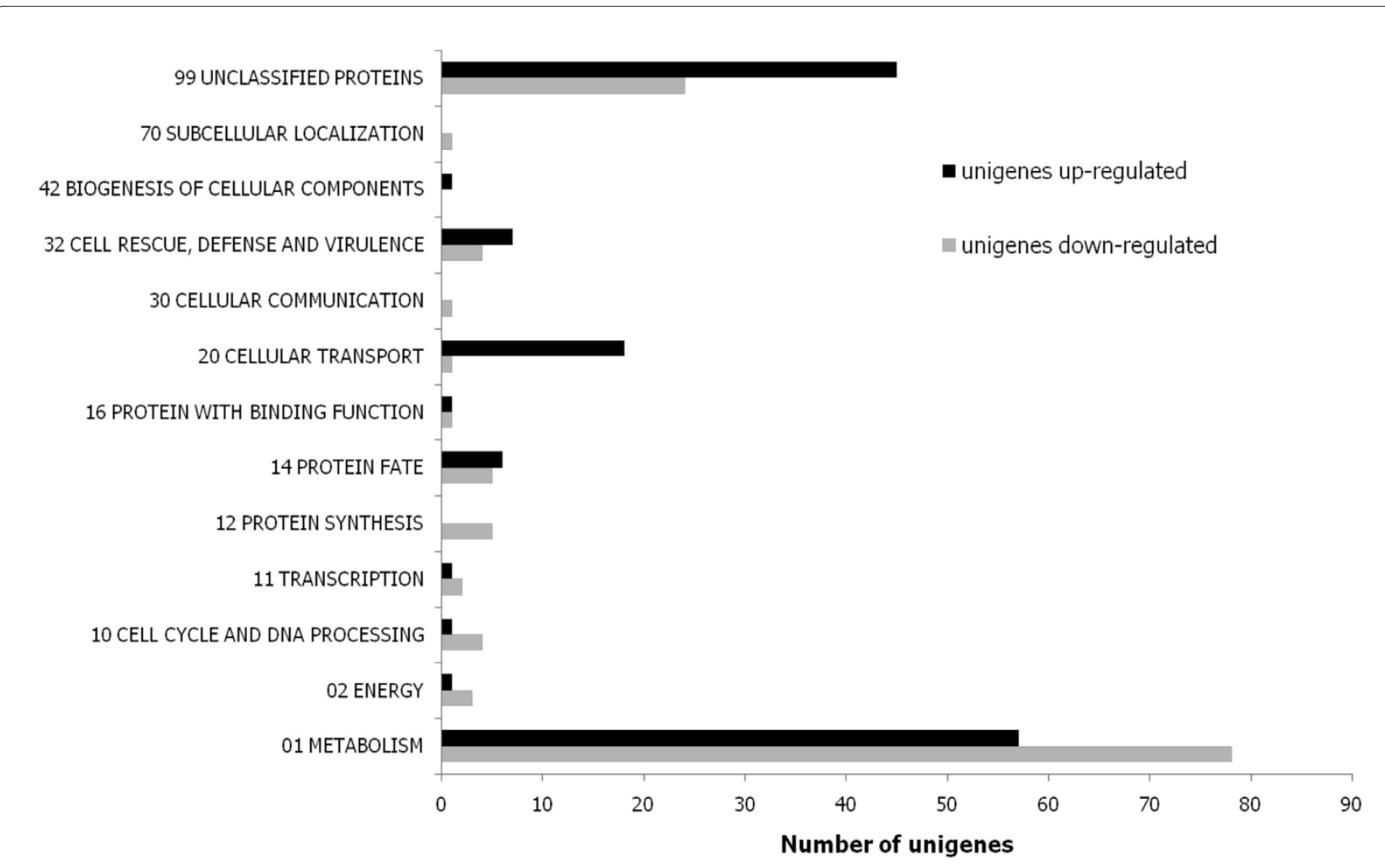

Figure 6 Functional categories of genes up- or down-regulated in S. rolfsii grown in EPSmax13 medium compared to growth in EPSmin 17 medium. An annotated list of all responsive genes, including fold change, $p$ value and classification, can be found in Additional file 15.

Scleroglucan levels were determined using isopropanol precipitation. Two volumes of isopropanol were mixed with one volume of culture broth and the resulting scleroglucan precipitate was filtered over a $74 \mu \mathrm{m}$ mesh filter. After evaporation of isopropanol, the precipitate was vacuum-dried for $2 \mathrm{~h}$ at $60^{\circ} \mathrm{C}$ and the dry weight of scleroglucan determined.

Oxalate levels in the culture supernatant were determined via HPLC (Knaur column $\mathrm{H}+$ ) using $0.05 \mathrm{M} \mathrm{H}_{2} \mathrm{SO}_{4}$ as solvent and an UV detector $(210 \mathrm{~nm})$.

\section{RNA isolation}

Due to the high amounts of EPS produced, extraction of intact total RNA from $S$. rolfsii cultures was only possible by using a caesium chloride-based ultracentrifugation method [48]. In brief, $1 \mathrm{~g}$ of S. rolfsii mycelium was harvested by filtration and frozen in liquid nitrogen. After homogenization using a dismembrator (Braun Biotech), the pulverized homogenate was resuspended in $5 \mathrm{ml}$ RNA extraction buffer (4 M guanidine isothiocyanate; 0.1 $\mathrm{M}$ Tris/ $\mathrm{HCl}, \mathrm{pH} 7.5 ; 1 \%$-Mercaptoethanol, 0.5\% N-laurylsarcosine). After centrifugation (5000 ×g, $10 \mathrm{~min}, \mathrm{RT})$, the supernatant was subjected to ultracentrifugation using $5 \mathrm{M}$ caesium chloride $(30,000 \times \mathrm{g}, 19 \mathrm{~h}, \mathrm{RT})$. The resulting RNA pellet was precipitated using 2 volumes of ice-cold $\mathrm{EtOH}$ (96\%) and 1/10 volumes of $8 \mathrm{M} \mathrm{LiCl}$.

\section{Suppression Subtractive Hybridization and Reverse Northern analysis}

Suppression subtractive hybridization was performed using the PCR-SelectTM cDNA subtraction kit and followed the manufacturer's instructions (Clontech). S. rolfsii mRNA extracted from EPSmax13 cultures was used as tester (mRNA population containing specifically expressed transcripts) and mRNA isolated from EPSmin17 as driver (mRNA population that is used for subtraction). The tester cDNAs enriched under EPSmax13 conditions were ligated into pUC18 vector (Fermentas) and transformed into Escherichia coli DH $5 \alpha$ (Gibco). Selected transformants were subjected to Reverse Northern analysis. Plasmid DNAs isolated from 180 randomly picked clones were slot-blotted onto positively Hybond-N nylon membranes (Amersham) and subjected to three independent hybridization runs using P32-labelled cDNAs generated from EPSmax13 and EPSmin17, respectively, as well as pUC18 plasmid DNA as probes. cDNAs were generated using Superscript II reverse transcriptase (Ambion). Hybridizations were per- 
Table 4: Unigenes selected from the microarray analysis that display increased or reduced expression in EPSmax13 medium compared to EPSmin 17 medium.

\begin{tabular}{|c|c|c|c|}
\hline Target ID & $\begin{array}{l}\text { Predicted function } \\
\text { (TBLASTx) }\end{array}$ & $P$ value & Log2Fold \\
\hline \multicolumn{4}{|c|}{ Carbohydrate metabolism } \\
\hline contig13845 & $\begin{array}{l}\text { Glycogen debranching } \\
\text { enzyme }\end{array}$ & $6.43 \mathrm{E}-03$ & 1.136 \\
\hline contig17335 & $\begin{array}{l}\text { Glycogen debranching } \\
\text { enzyme }\end{array}$ & $4.42 \mathrm{E}-02$ & 1.174 \\
\hline contig18482 & $\begin{array}{l}\text { Glycogen debranching } \\
\text { enzyme }\end{array}$ & $8.15 \mathrm{E}-03$ & 1.074 \\
\hline contig19066 & UDP-glucose-4-epimerase & $3.25 \mathrm{E}-03$ & 1.012 \\
\hline contig20926 & $\begin{array}{l}\text { GH16 beta-1,3-glucan } \\
\text { recognition protein }\end{array}$ & $1.60 \mathrm{E}-02$ & 1.542 \\
\hline contig01604 & $\begin{array}{l}\text { GH16 beta-1,3-glucan } \\
\text { recognition protein }\end{array}$ & $1.37 \mathrm{E}-02$ & 1.540 \\
\hline $\mathrm{C} 2$ & Glycogen phosphorylase & $4.65 \mathrm{E}-02$ & 1.493 \\
\hline contig04502 & Glycoside hydrolase family 31 & $2.78 \mathrm{E}-02$ & 1.455 \\
\hline contig08391 & Glycoside hydrolase family 31 & $1.30 \mathrm{E}-02$ & 1.102 \\
\hline contig20411 & Glycoside hydrolase family 63 & $1.75 \mathrm{E}-03$ & 1.056 \\
\hline F3 & $\begin{array}{l}\text { Mannitol-1-phosphate } \\
\text { dehydrogenase }\end{array}$ & $1.77 \mathrm{E}-03$ & 1.305 \\
\hline contig07858 & Formate dehydrogenase & $1.97 \mathrm{E}-02$ & 1.307 \\
\hline contig11312 & Formate dehydrogenase & $6.59 \mathrm{E}-04$ & 2.341 \\
\hline contig13166 & Formate dehydrogenase & $1.15 \mathrm{E}-03$ & 2.826 \\
\hline contig16572 & Formate dehydrogenase & $1.25 \mathrm{E}-03$ & 2.611 \\
\hline contig16914 & Formate dehydrogenase & $6.76 \mathrm{E}-04$ & 2.570 \\
\hline contig17132 & Formate dehydrogenase & $4.23 \mathrm{E}-02$ & 2.360 \\
\hline contig21037 & Formate dehydrogenase & $1.59 \mathrm{E}-03$ & 2.231 \\
\hline contig21586 & Endocellulase & $6.16 \mathrm{E}-03$ & -2.391 \\
\hline contig06887 & Endocellulase & $4.85 \mathrm{E}-02$ & -1.571 \\
\hline contig16192 & Endocellulase & $4.08 \mathrm{E}-03$ & -2.419 \\
\hline contig15791 & Endocellulase & $1.89 \mathrm{E}-02$ & -3.138 \\
\hline contig08327 & Glucoamylase G2 & $1.39 \mathrm{E}-02$ & -1.069 \\
\hline contig04589 & Glucoamylase G2 & $2.43 \mathrm{E}-03$ & -2.330 \\
\hline contig03614 & Exo-beta-1,3-glucanase & $7.25 \mathrm{E}-04$ & -2.473 \\
\hline contig10472 & $\begin{array}{l}\text { UDP-glucuronosyl/UDP- } \\
\text { glucosyl transferase }\end{array}$ & $3.21 \mathrm{E}-02$ & -1.403 \\
\hline
\end{tabular}

Lipid metabolism
contig04863
contig19483
contig18170
contig16238
contig16026
contig01140
contig08736

Squalene monooxygenase

4.27E-02

2.255

Squalene monooxygenase

4.21E-02

2.007

Squalene monooxygenase

Squalene monooxygenase

$4.40 \mathrm{E}-02$

1.861

2.91E-02

1.546

Sphingolipid hydroxylase

4.69E-03

1.858

Sphingolipid hydroxylase

3.75E-02

1.741

Sphingolipid hydroxylase 
Table 4: Unigenes selected from the microarray analysis that display increased or reduced expression in EPSmax13 medium compared to EPSmin 17 medium. (Continued)

\begin{tabular}{llll}
\hline contig19971 & Sphingolipid hydroxylase & $1.05 \mathrm{E}-02$ & 1.610 \\
contig03880 & Sphingolipid hydroxylase & $1.43 \mathrm{E}-02$ & 1.291 \\
contig11092 & C-4 sterol methyl oxidase & $2.49 \mathrm{E}-02$ & 1.622 \\
contig21591 & C-4 sterol methyl oxidase & $3.28 \mathrm{E}-02$ & 1.524 \\
contig03744 & C-4 sterol methyl oxidase & $4.50 \mathrm{E}-03$ & 1.754 \\
contig14837 & C-5 sterol desaturase & $7.16 \mathrm{E}-03$ & 1.872 \\
\hline
\end{tabular}

formed using the Rapid-Hyb buffer system (Amersham) and followed the manufacturer's instructions.

\section{4 pyrosequencing}

Mixed cDNA populations obtained from S. rolfsii were sequenced in triplicate runs by 454 Life Sciences (Branford, USA). For this purpose, total RNA was isolated from $37 \mathrm{~h}$ old cultures of $S$. rolfsii grown in EPSmin17 and EPSmax13 medium (see above). Both RNA populations were pooled in a 1:1 ratio to guarantee equal occurrence and putative constitutively expressed genes (glycerol phosphate dehydrogenase, gpdS; glucoamylase G2, accession number D49448) were used for normalization. cDNAs were synthesized using the Clontech's SMART System protocol modified by AGOWA (Berlin, Germany). The cDNA library was sequenced by the ultrafast pyrosequencing method (454 Life Sciences).

\section{PCR screening}

Oxalate oxidase metabolizes oxalate directly to $\mathrm{CO}_{2}$ and $\mathrm{H}_{2} \mathrm{O}_{2}$ (enzyme no. 11 in Figure 4) and is found mainly in plants [49-51] but also in basidiomycetes [41]. Sequences from barley (oxoX, CAA74595) and the fungus Ceriopsis subvermispora (CAD91553) were used to identify regions of high homology (data not shown), inside of which primers were designed (Bar 1, GGTACGAACACGTGGGC; Bar2, CCGGCCTCCACCCGAAGAG) to amplify a potential oxalate oxidase from $S$. rolfsii genomic DNA (see below). Using this primer pair, a $~ 850$ bp fragment was isolated.

Oxalate decarboxylase degrades oxalate to formate and $\mathrm{CO}_{2}$ (enzyme no. 7 in Figure 4). Oxalate decarboxylases are present in the brown rot fungi Postia placenta [52] and Flammulina velutipes [42]. A region within the $F$. velutipes oxdc gene (AF200683), which is highly conserved among oxalate decarboxylases, was used as a template for the design of specific primers (Oxdc1, ATTAAGGATCCATCCATCGCATTTCCGATG; Oxdc2, AATACCDAYGTAGGAAATCATATCCGGCCG). For both PCR reactions, different annealing temperatures and elongation times were tested (not shown).

\section{Genomic DNA extraction}

S. rolfsii was cultivated in $100 \mathrm{ml}$ EPSmin 17 medium at $28^{\circ} \mathrm{C}, 250 \mathrm{rpm}$ using magnetic stirrers. After $48 \mathrm{~h}$ of cultivation, mycelium was harvested by filtration through a piece of gauze and washed twice with hot water $\left(85^{\circ} \mathrm{C}\right)$ to remove scleroglucan. The mycelium was frozen in liquid nitrogen and genomic DNA extracted following a protocol described for Aspergillus nidulans [53].

\section{Microarray analysis}

Tailor-made microarrays (44K multiplex chip, Agilent) were designed by imaGenes (Berlin, Germany) using an in-house developed method for empirical selection of best performing probes for each gene (Pre Selection Strategy). Briefly, up to ten probes were designed for each of the 454 and $\mathrm{SSH}$ unigenes as well as for the oxox gene (60 bp long oligomers). The $244 \mathrm{~K}$ Agilent test array was hybridized with pooled Cy3-labeled cRNAs gained form EPSmax13 and EPSmin17 cultures (see above) and (in average) two of the best performing oligos were selected for each unigene.

For comparative expression profiling, total RNA was isolated from $S$. rolfsii, cultured for $37 \mathrm{~h}$ in EPSmax 13 and EPSmin17 media as described above. RNA quality control, synthesis of Cy3-labeled cRNA including cRNA purification and cRNA quality control, microarray hybridization, scanning and data extraction (Agilent's feature extraction software) were performed by imaGenes $\mathrm{GmbH}$. The complete set of transcriptional raw data is available as Additional files 8, 9, 10, 11, 12 and 13 and has additionally been archived at Gene Expression Omnibus http://www.ncbi.nlm.nih.gov/geo under accession number GSE21040. Expression data were analyzed by imaGenes $\mathrm{GmbH}$ using an in-house developed data analysis pipeline. After quantile normalization, genes were defined as differentially expressed if their expression levels varied at least 2 fold in EPSmax13 samples compared to EPSmin17 samples and if the difference was statistically significant (Student's t-test, $P$-value cut-off of 0.05). 


\section{Additional material}

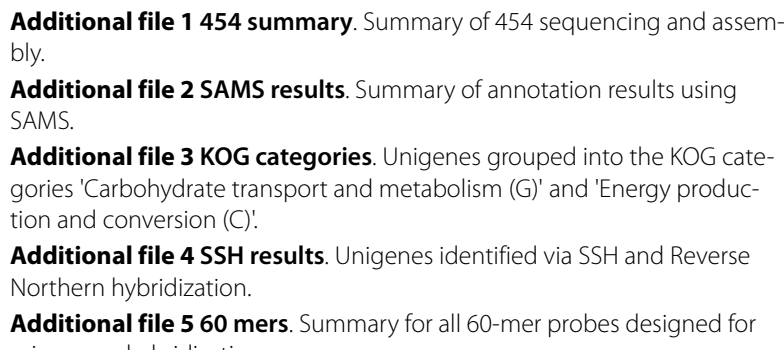

Additional file 3 KOG categories. Unigenes grouped into the KOG categories 'Carbohydrate transport and metabolism (G)' and 'Energy production and conversion (C)'.

Additional file $4 \mathrm{SSH}$ results. Unigenes identified via SSH and Reverse Northern hybridization.

Additional file $\mathbf{5} \mathbf{6 0}$ mers. Summary for all 60-mer probes designed for microarray hybridization.

Additional file $\mathbf{6}$ selected 60 mers. 60-mer probes used for comparative microarray hybridization.

Additional file $\mathbf{7}$ Sample Key. Sample key for comparative microarray hybridization.

Additional file 8 251706710004_2. Raw data for experiment

EPSmax13_37 h, Sample A.

Additional file 9 251706710005_4. Raw data for experiment

EPSmax13_37 h, Sample B.

Additional file 10 251706710005_1. Raw data for experiment

EPSmax13_37 h, Sample C.

Additional file 11 251706710005_3. Raw data for experiment

EPSmin17_37 h, Sample A.

Additional file 12 251706710004_4. Raw data for experiment

EPSmin17_37 h, Sample B.

Additional file 13 251706710006_4. Raw data for experiment

EPSmin17_37 h, Sample C.

Additional file 14 Dendrogram. Dendrogram of the clustering hybridization experiment based on mean expression values.

Additional file 15 Differentially expressed unigenes. Differentially expressed unigenes in EPSmax13 compared to EPSmin17 medium.

\section{Authors' contributions}

JS carried out the molecular genetic studies, sequence annotations and microarray analyses and performed the oxalate analyses. LF and JS carried out the SSH approach and extracted RNA and scleroglucan. TB participated in the bioinformatics and functional analyses. JS, DM and US participated in the design of the study. VM and VS conceived of, designed and coordinated the study. JS and VM wrote the manuscript. All authors read and approved the final manuscript.

\section{Acknowledgements}

The authors would like to thank Barbara Walewska, Boris Winter and Mirine Choi for technical assistance and the German Federal Ministry of Research and Education for financial support (BMBF grant 0313397).

\section{Author Details}

${ }^{1}$ Chair of Chemistry of Biogenic Resources, Straubing Centre of Science, Technische Universität München, Schulgasse 16, 94315 Straubing, Germany, 2Department of Microbiology and Genetics, Berlin University of Technology, Gustav-Meyer-Allee 25, 13355 Berlin, Germany, ${ }^{3}$ Computational Genomics, Center for Biotechnology (CeBiTec), Bielefeld University, D-33594 Bielefeld, Germany, 4Degussa Food Ingredients GmbH, Lise Meitner Str. 34, 85354 Freising, Germany, 5 Molecular Microbiology and Biotechnology, Institute of Biology, Leiden University, 2333 BE Leiden, The Netherlands and ${ }^{6}$ PolyPhag GmbH, Robert-Rössle-Str. 10, 13125 Berlin, Germany

Received: 23 December 2009 Accepted: 26 May 2010 Published: 26 May 2010

\section{References}

1. Paintin RD: Notes on the parasitology of Sclerotium rolfsii. Mycologia $1928,20(1): 22-26$

2. Mordue JEM: Corticium rolfsii. CMI description of Pathogenic Fungi and Bacteria no 410 1974, 41:
3. Wydra K: Collection and determination of root and stem rot pathogens. Annual Report IITA 1996, 68:

4. Brigand G: Scleroglucan. In Industrial Gums 3rd edition. New York: Academic Press; 1993:461-472.

5. Sandford PA: Exocellular, microbial polysaccharides. Adv Carbohydr Chem Biochem 1979, 36:265-313.

6. EL Ouriaghli Y, Francois J, Sarazin D, Nguyen Truong D: Influence of nonionic surfactant on aggregation state of scleroglucan in aqueous solution. Carbohydr Polym 1992, 17(4):305-312.

7. Survase SA, Saudagar PS, Bajaj IB, Singhal RS: Scleroglucan: Fermentative Production, Downstream Processing and Applications. Food Technol Biotechnol 2007, 45(2):107-118.

8. Fariña JI, Viñarta SC, Cattaneo M, Figueroa LIC: Structural stability of Sclerotium rolfsii ATCC $201126 \beta$-glucan with fermentation time: a chemical, infrared spectroscopic and enzymatic approach. J Appl Microbiol 2009, 106(1):221-232.

9. Coviello T, Alhaique F, Parisi C, Matricardi P, Bocchinfuso G, Grassi M: A new polysaccharidic gel matrix for drug delivery: preparation and mechanical properties. J Control Release 2005, 102(3):643-656.

10. Coviello T, Grassi M, Palleschi A, Bocchinfuso G, Coluzzi G, Banishoeib F, Alhaique F: A new scleroglucan/borax hydrogel: swelling and drug release studies. Int J Pharm 2005, 289(1-2):97-107.

11. Giavasis I, Harvey LM, MCNeil B: Scleroglucan. In Biopolymers: Polysaccharides II Volume 6. Edited by: EJ S. Weinheim: Wiley-VCH; 2002:37-60.

12. Sutherland IW: Microbial polysaccharides-a comparison with eukaryotic polymers. Sym Soc Exp Biol 1989, 43:389-402.

13. Schmid F, Stone BA, Brownlee RT, McDougall BM, Seviour RJ: Structure and assembly of epiglucan, the extracellular (1-->3;1-->6)-beta-glucan produced by the fungus Epicoccum nigrum strain F19. Carbohydr Res 2006, 341(3):365-373.

14. Batra KK, Nordin JH, Kirkwood S: Biosynthesis of the [beta]--glucan of Sclerotium rolfsii sacc. Direction of chain propagation and the insertion of the branch residues. Carbohyd Res 1969, 9(2):221-229.

15. Farina Jl, Sineriz F, Molina, Perotti NI: High scleroglucan production by Sclerotium rolfsii: Influence of medium composition. Biotechnol Lett 1998, 20(9):825-831.

16. Maxwell DP, Bateman DF: Influence of carbon source and $\mathrm{pH}$ on oxalate accumulation in culture filtrates of S. rolfsii. Phytopathology 1965 , 58:1351-1355.

17. Wang $Y$, McNeil B: Scleroglucan and oxalic acid formation by Sclerotium glucanicum in sucrose supplemented fermentation. Biotechnol Lett 1994, 16:605-610.

18. Lee K: Characterization of scleroglucan fermentation by Sclerotium rolfsii in terms of cell, scleroglucan and by-product, oxalic acid concentrations, viscosity and molecular weight distribution. Irvine: California; 1998.

19. Wang Y, McNeil B: Scleroglucan. Crit Rev Biotechno/ 1996, 16(3):185-215.

20. Schilling BM, Henning A, Rau U: Repression of oxalic acid biosynthesis in the unsterile scleroglucan production process with Sclerotium rolfsii ATCC 15205. Bioprocess Eng 2000, 22:51-55.

21. Survase SA, Saudagar PS, Singhal RS: Enhanced production of scleroglucan by Sclerotium rolfsii MTCC 2156 by use of metabolic precursors. Bioresour Technol 2007, 98(2):410-415.

22. Survase SA, Saudagar PS, Singhal RS: Use of complex media for the production of scleroglucan by Sclerotium rolfsii MTCC 2156. Bioresour Technol 2007, 98(7):1509-1512.

23. Bateman DF, Beer SV: Simultaneous production and synergistic action of oxalic acid and polygalacturonase during pathogenesis by Sclerotium rolfsii. Phytopathology 1965, 55:204-211.

24. Dutton MV, Evans CS: Oxalate production by fungi: its role in pathogenicity and ecology in the soil environment. Can J of Bot 1996, 42:881-895.

25. Goodell b, Jellison J, Liu J, Daniel G, Pasczynski A, Fekete F, Krishnamurthy $\mathrm{S}$, Jun L, Xu G: Low molecular weight chelators and phenolic compounds isolated from wood decay fungi and their role in the fungal biodegradation of wood. J Biotechnol 1995, 53:133-162.

26. Munir E, Yoon JJ, Tokimatsu T, Hattori T, Shimada M: A physiological role for oxalic acid biosynthesis in the wood-rotting basidiomycete Fomitopsis palustris. Proc Natl Acad Sci USA 2001, 98(20):11126-11130. 
27. Shimadaa M, Akamtsub Y, Tokimatsua T, Miia K, Hattoria T: Possible biochemical roles of oxalic acid as a low molecular weight compound involved in brown-rot and white-rot wood decays. J Biotechnol 2007, 53(2-3):103-113.

28. Green F, Clausen CA, Kuster TA, Highley TL: Induction of polygalacturonase and the formation of oxalic acid by pectin in brown-rot fungi. World J Microbiol Biotechnol 1995, 11(5):519-524.

29. Green IF, Tschernitz J, Kuster TA, Highley TL: Hydrolysis of bordered pits during colonization of conifers by brown-rot decay. The International Research Group on Wood Preservation, 26th Annual Meeting Helsingør, Denmark 11-16 June 1995. Helsingør 1995.

30. Errakhi R, Meimoun P, Lehner A, Vidal G, Briand J, Corbineau F, Rona JP, Bouteau F: Anion channel activity is necessary to induce ethylene synthesis and programmed cell death in response to oxalic acid. J Exp Bot 2008, 59(11):3121-3129.

31. Lehner A, Meimoun P, Errakhi R, Madiona K, Barakate M, Bouteau F: Toxic and signalling effects of oxalic acid oxalic acid-natural born killer or natural born protector? Plant Signal Behav 2008, 3(9):746-748.

32. Kim KS, Min JY, Dickman MB: Oxalic acid is an elicitor of plant programmed cell death during Sclerotinia sclerotiorum disease development. Mol Plant Microbe Interact 2008, 21(5):605-612.

33. Bekel T, Henckel K, Kuster H, Meyer F, Mittard Runte V, Neuweger H, Paarmann D, Rupp O, Zakrzewski M, puhler A, Stoye J, Goesman A: The sequence analysis and management system - SAMS-2.0: data management and sequence analysis adapted to changing requirements from traditional sanger sequencing to ultrafast sequencing technologies. J Biotechnol 2009, 140(1-2):3-12.

34. Altschul SF, Gish W, Miller W, Myers EW, Lipman DJ: Basic local alignment search tool. J Mol Biol 1990, 215(3):403-410.

35. Kubicek CP, Schrefferl-Kunar GE, Wöhrer W, Rohr W: Evidence for a cytoplasmic pathway of oxalate biosynthesis in Aspergillus niger. Environ Microbiol 1988, 54(3):633-637.

36. Han Y, Joosten HJ, Niu W, Zhao Z, Mariano PS, McCalman M, van Kan J, Schaap PJ, Dunaway-Mariano D: Oxaloacetate hydrolase, the C-C bond lyase of oxalate secreting fungi. J Biol Chem 2007, 282(13):9581-9590.

37. Rio M, de Oliveira B, de Tomazella D, Silva J, Pereira G: Production of calcium oxalate crystals by the basidiomycete Moniliophthora perniciosa, the causal agent of Witches' Broom disease of cacao. Curr Microbiol 2008, 56(4):363-370.

38. Maxwell DP, Bateman DF: Oxalic acid biosynthesis by Sclerotium rolfsii. Phytopathology 1968, 58:1635-1642.

39. Takaya N, Uchimura H, Lai Y, Shoun H: Transcriptional control of nitric oxide reductase gene (CYP55) in the fungal denitrifier Fusarium oxysporum. Biosci Biotechnol Biochem 2002, 66(5):1039-1045.

40. Uchimura H, Enjoji H, Seki T, Taguchi A, Takaya N, Shoun H: Nitrate reductase-formate dehydrogenase couple involved in the fungal denitrification by Fusarium oxysporum. J Biochem 2002, 131(4):579-586.

41. Escutia MR, Bowater $L$, Edwards A, Bottrill AR, Burrell MR, Polanco R, Vicuna $\mathrm{R}$, Bornemann S: Cloning and sequencing of two Ceriporiopsis subvermispora bicupin oxalate oxidase allelic isoforms: implications for the reaction specificity of oxalate oxidases and decarboxylases. Appl Environ Microbiol 2005, 71(7):3608-3616.

42. Azam M, Kesarwani M, Chakraborty S, Natarajan K, Datta A: Cloning and characterization of the 5 '-flanking region of the oxalate decarboxylase gene from Flammulina velutipes. Biochem J 2002, 367(Pt 1):67-75.

43. Ruepp A, Zollner A, Maier D, Albermann K, Hani J, Mokrejs M, Tetko I, Guldener U, Mannhaupt G, Munsterkotter M, Mewes HW: The FunCat, a functional annotation scheme for systematic classification of proteins from whole genomes. Nucleic Acids Res 2004, 32(18):5539-5545.

44. Chen LZ, Li DH, Song LR, Hu CX, Wang GH, Liu YD: Effects of salt stress on carbohydrate metabolism in desert soil alga Microcoleus vaginatus Gom. J Integr Plant Biol 2006, 48(8):914-919.

45. Mikherjee SK, Samadarr KR: The correlation between salt tolerance and extracellular polysaccharide production in Rhizobium. Microbes Environ 1997, 12(1):9-13.

46. Ozturk S, Aslim B: Modification of exopolysaccharide composition and production by three cyanobacterial isolates under salt stress. Environ Sci Pollut Res Int 2010, 7(3):595-602.

47. Nagarajan T, Vanderleyden J, Tripathi AK: Identification of salt stress inducible genes that control cell envelope related functions in Azospirillum brasilense Sp7. Mol Genet Genomics 2007, 278(1):43-51.
48. Chirgwin JM, Przybyla AE, MacDonald RJ, Rutter WJ: Isolation of biologically active ribonucleic acid from sources enriched in ribonuclease. Biochemistry 1979, 18(24):5294-5299.

49. Lane BG: Oxalate oxidases and differentiating surface structure in wheat: germins. Biochem J 2000, 349(Pt 1):309-321.

50. Lane BG, Dunwell JM, Ray JA, Schmitt MR, Cuming AC: Germin, a protein marker of early plant development, is an oxalate oxidase. J Biol Chem 1993, 268(17):12239-12242.

51. Dumas B, Freyssinet G, Pallett KE: Tissue-specific expression of germinlike oxalate oxidase during development and fungal infection of barley seedlings. Plant Physiol 1995, 107(4):1091-1096.

52. Micales JA: Oxalate decarboxylase in the brown-rot wood decay fungus Postia placenta. Mater Organismen 1995, 29(3):177-186.

53. Yelton MM, Hamer JE, Timberlake WE: Transformation of Aspergillus nidulans by using a trpC plasmid. Proc Natl Acad Sci USA 1984, 81(5):1470-1474.

doi: 10.1186/1471-2164-11-329

Cite this article as: Schmid et al., Transcriptome sequencing and comparative transcriptome analysis of the scleroglucan producer Sclerotium rolfsii BMC Genomics 2010, 11:329

\section{Submit your next manuscript to BioMed Centra and take full advantage of:}

- Convenient online submission

- Thorough peer review

- No space constraints or color figure charges

- Immediate publication on acceptance

- Inclusion in PubMed, CAS, Scopus and Google Scholar

- Research which is freely available for redistribution

Submit your manuscript at www.biomedcentral.com/submit
C) BioMed Central 